\title{
Leading Role of the Public Sector in the Digitalisation of Economy
}

\author{
Irina Gersonskaya \\ Department of Economics and Finances \\ Russian Presidential Academy of National Economy and Public Administration \\ Internacionalnaja str. 3, 398050 Lipetsk \\ Russian Federation \\ e-mail: g3071971@ya.ru
}

\begin{abstract}
The implementation of information and communication technologies (ICTs) in the national economy typically goes hand in hand with their use in the public sector. This sector constitutes the driver of the entire system of the national economy and directly directs transformational processes. The rise of ICTs caused significant changes in all sectors of the national economy.

It is apparent that the implementation of "electronic government" not only increases the efficiency of the public administration system, but also contributes to an improvement of quality of public services provided to entrepreneurs and regular citizens.

We argue that public sector reforms can foster the development of the national economy as well as to promote sustainable economic growth. Today, the ongoing transformational processes include not only the introduction of digital technologies in all sectors of the national economy, but also positive changes in the leadership styles of government structures and methods of government. However, in the process of digitalisation of the national economy, there are still many issues related to the use and implementation of ICTs. Our paper argues that the public sector might help solving some of the key problems related to the digitalization processes and therefore plays a leading role in the national economy.
\end{abstract}

\section{Introduction}

Nowadays, economic development in Russian Federation is undergoing numerous process accompanied with the restructuring of the national economy and the changes in the state institutions. All of these is aimed at creating the drivers for inclusive economic growth. Digitalisation of the Russian economy represents one of its key elements since ICTs occupy a key place in the transformation of the entire social and economic system of the state and in any realm of everyday life (Afonasova et al. 2019; Veselovsky et al. 2019). Overall, it seems that the public sector plays the main role in the digitalisation because only the state can promptly and efficiently influence the restructuring of the socio-economic systems.

In a mixed economy, the public sector is a necessary element of the national economy (Bolumole et al. 2015). Such a sector is a multilevel state institution, the functioning of which is associated primarily with the implementation of state socio-economic policy. Russian Federation is no exception and has a fairly developed public sector (Roshchanka and Evans 2016). Public sector includes the following elements:

- Public administration sector, which is a leader in the system of the national economy by virtue of its implementation of the function of state regulation of the economy;

- "State business sector" consisting of state-owned enterprises and corporations that operate in the important sectors of the national economy and make additional income for the state;

- State social sector, which produces the necessary public goods and provides the population with numerous social services.

Traditionally, public sector in Russia is envisaged to solve social issues and to help further economic development (see Omonov and Veretennikova 2016). Today, Russian public sector supports inclusive (socially oriented) economic growth using the approaches of innovative management as well as digital technologies that might help the development of economy.

In order to foster digitalisation in all social and economic processes, Russia adapted a strategy for the development of the information society (covering the period of 2017-2030). The strategy includes integrated implementation of modern information technologies in all areas (including the public sector).

To develop this strategy, the government of the Russian Federation relies upon the program entitled "Digital Economy of the Russian Federation" which should create conditions for the development of a knowledge-based society, improve the well-being and quality of life of citizens, and increase the availability and quality of goods and services. Moreover, it is envisaged to support the use of modern digital technologies, improve digital 
competences, ease the availability and quality of public services for citizens, as well as increase digital security (Digital Economy of the Russian Federation 2017).

Today, digitization processes might help to support innovative and socio-economic development, contribute to the rise of human capital and increase social well-being. In addition, they have the potential to contribute to the inclusive growth. In our opinion, institutional structures of the public sector play a leading role in the organization of digital transformation processes taking place in the national economy system.

\section{Public sector as a leader in transformational digital processes}

With the direct involvement of the public sector of the economy, and above all the functioning of the state management system, dynamic social development takes place in Russia, including the digitization of the economy, the creation of "economic growth points" and the level of public well-being (Kotov 2018). In other words, the state sector can become the "driving force" of the digital transformation of the entire system of the national economy.

In Russia, there has been an "electronic government" system for several years, which is a comprehensive mechanism of interaction of all elements of the national economy, namely the public sector, households and the enterprise sector. Electronic administration is a new form of organizing the activities of public authorities, which, thanks to the widespread use of information and communication technologies, offers a qualitatively new level of efficiency and convenience in obtaining public services and information on the results of activities (see Arkhipova 2016).

In Russia, e-administration exists in the form of modern information and communication systems in the infrastructure of the public administration subsector, which are involved in the provision of various types of public services. In our opinion, the introduction and rational use of the e-government system enabled the public sector of the Russian economy to use modern information and communication technologies to ensure coordination of management measures and a fairly close relationship between all their elements. Today, e-government in Russia provides all the necessary basic components of such a management system:

- $\quad$ single electronic portal of public services;

- $\quad$ single electronic portal of public procurement;

- $\quad$ state electronic information centre;

- development of a network of multifunctional centres in the country;

- centres of public access to information and various types of call centres;

- $\quad$ system of interagency electronic interaction between public sector entities, etc.

In the public sector, the creation of an e-government system has led to close online interaction between its individual elements and institutional units. At the same time, document management was optimized in state structures and the speed of managerial decision-making was increased. The successful functioning of egovernment in Russia also allowed for the population and entrepreneurs to reduce queues in state bodies, as well as to speed up and simplify the receipt of documentation.

We believe that the technological conditions for the digital transformation of the public sector of the economy in Russia, and especially in the process of providing electronic public services, are somewhat worse than in developed world powers, and above all, in terms of providing households with digital devices and communication between them via the Internet. This factor significantly slows down the development of the digital society in Russia, even though the government provides a tool for convenient and secure online identification of a unified system of identification and authentication the purpose of which is to provide integration of various channels access to e-government (see Zemskova 2018). The benefits of digitalizing the public service delivery process are shown in Figure 1.

In the process of transition to digitalization of society, the public sector of the Russian economy faces a large-scale task of digital transformation, which provides not only a digital transformation of the institutional structures of the public sector, aimed at significantly improving the efficiency of its functioning, but also expanding the types and forms of public services provided in electronic form and improve the quality of their provision. 


\begin{tabular}{|c|c|}
\hline Digital processes by types of public services in order to increase efficiency, improve quality \\
and reduce their cost
\end{tabular}

Fig. 1 Possible benefits of digital public services in Russia Source: Own results

It appears that the digitalization process of public services might cause increased efficiency both in the public sector and in the national economy. Such processes allow expanding the range of types and forms of public services for the population and entrepreneurs. At the same time, government spending is significantly reduced due to a reduction in excess functions.

Information technologies in the public administration system are changing and they are being replaced by more advanced digital technologies. It is the modification of information and communication technologies that leads to the inevitability of the process of transforming the entire public sector of the economy, and not just the egovernment system. Today, the main areas of development of digital technologies are the following:

- $\quad$ application of "cloud technologies";

- $\quad$ organization and use of "big data" and analytics based on them;

- $\quad$ ensuring mobility and the use of mobile technologies;

- widespread use of social communication technologies;

- "Internet of things" (IoT) which repreresents the creation and use of technology, provided that various objects have built-in devices for interacting with each other or the external environment;

- $\quad$ ensuring a high level of information security (see Arkhipova 2016).

Nowadays, the Russian public sector still lags behind in the level of digitalization, the share of the digital economy in GDP, and the average delay in mastering the technologies used in the leading countries. The share of the digital economy in Russia's GDP is about 4\%, which is 2-3 times lower than in the developed Western economies (see Zemskova 2018). Therefore, there should be an emphasis made on information and digital data and this should become the country's priority.

At the same time, boosting business processes in the public sector should cut management costs and increase labour productivity due to the digital transformation, but only in case of the high quality of provided public services. Broader access to the electronic public services is required. Thence, modern management methods based on digital technologies might be of a great help for achieving all of the above tasks.

\section{Advantages and problems of digitalization}

The creation of a "digital economy" system in Russia is also associated with the digitalization processes in the subsector of state enterprises and corporations by creating "digital companies". Digitalization of business processes 
in the state's business sector will improve the efficiency and effectiveness of business process management. To create "digital companies", first of all, specialized information systems are needed that provide not only accounting and analytical processes, but also designed for operational management of business processes and flexible response to changing market conditions, since state-owned enterprises and corporations are interested in obtaining arrived. But, however, in this case as well, a person will have the function of control over automated production to monitor artificial intelligence (Korogodin 2019).

Digitalization of business processes in state-owned enterprises and corporations will significantly contribute to the growth of business value and increase the efficiency of financial and economic activities, bringing additional revenue to the state budget. Figure 2 shows the possible benefits of digital technology in public enterprise.

\begin{tabular}{|c|c|}
\hline \multicolumn{2}{|c|}{$\begin{array}{l}\text { Digitalization of the subsector of state enterprises and } \\
\text { corporations }\end{array}$} \\
\hline \multicolumn{2}{|c|}{$\begin{array}{l}\text { Digital business processes by sectors of the national economy in order to increase business } \\
\text { value and increase efficiency }\end{array}$} \\
\hline V & $\downarrow$ \\
\hline Sales and profit growth, cost reduction & $\begin{array}{l}\text { Increased Production Capacity and } \\
\text { Efficiency }\end{array}$ \\
\hline$\downarrow$ & $\downarrow$ \\
\hline Latest business processes & Production modernization \\
\hline Models of modernization of the economy & Using new tools \\
\hline Increase product quality & Using new tools \\
\hline The expansion of the customer base & Competitive growth \\
\hline Labor productivity growth & Best Market Development Time \\
\hline Lower production costs & Increase efficiency \\
\hline Profitability increase & Enterprise value growth \\
\hline
\end{tabular}

Fig. 2. Benefits of introducing digital technology in the public sector Source: Own results

Digitalization of state business should cover all aspects of the current, investment and financial activities of state enterprises and corporations. Therefore, in the "digital company" for the effective management of business processes, a comprehensive electronic information system should be introduced, which will generalize all the most important aspects of conducting financial and economic activities of state-owned enterprises. However, the creation of such a system that effectively works in the subsector of state-owned enterprises and corporations for managing business processes in the so-called "digital field" mode is currently a rather serious problem. Creating a digital company is difficult due to the fact that digital developments and programs for the purpose of managing business processes do not meet the conditions of effective state management in the process of doing business.

In our opinion, today, when creating "digital companies" in the public sector of the economy, there are certain difficulties associated primarily with the rather low level of use of digital technologies in the business sector as a whole. A rather low level of digitalization of Russian companies is observed, not all business structures have websites and access to broadband Internet. In addition, one has to understand that digital technologies still constitute a negligible share in Russia. For example, 66\% of companies use cloud services in the Finnish business sector, 48\% in Sweden, 47\% in Japan, and 35\% in the UK. In Finland, 23\% of companies use RFID technology, $16 \%$ in Germany, $13 \%$ in Italy, $12 \%$ in Sweden and Estonia, and 11\% in France (Abdrakhmanov et al. 2019). In Russia, cloud services are used by the $23 \%$ of business companies (only $6 \%$ of them use RFID technologies).

Russian scientist calculated the business digitalization index for the leading countries of the world in 2017 which characterizes the level of use of broadband Internet, cloud services, RFID technologies, ERP systems, and the involvement of business sector organizations in electronic commerce (Abdrakhmanov et al. 2019). Its values are shown in Figure 3 


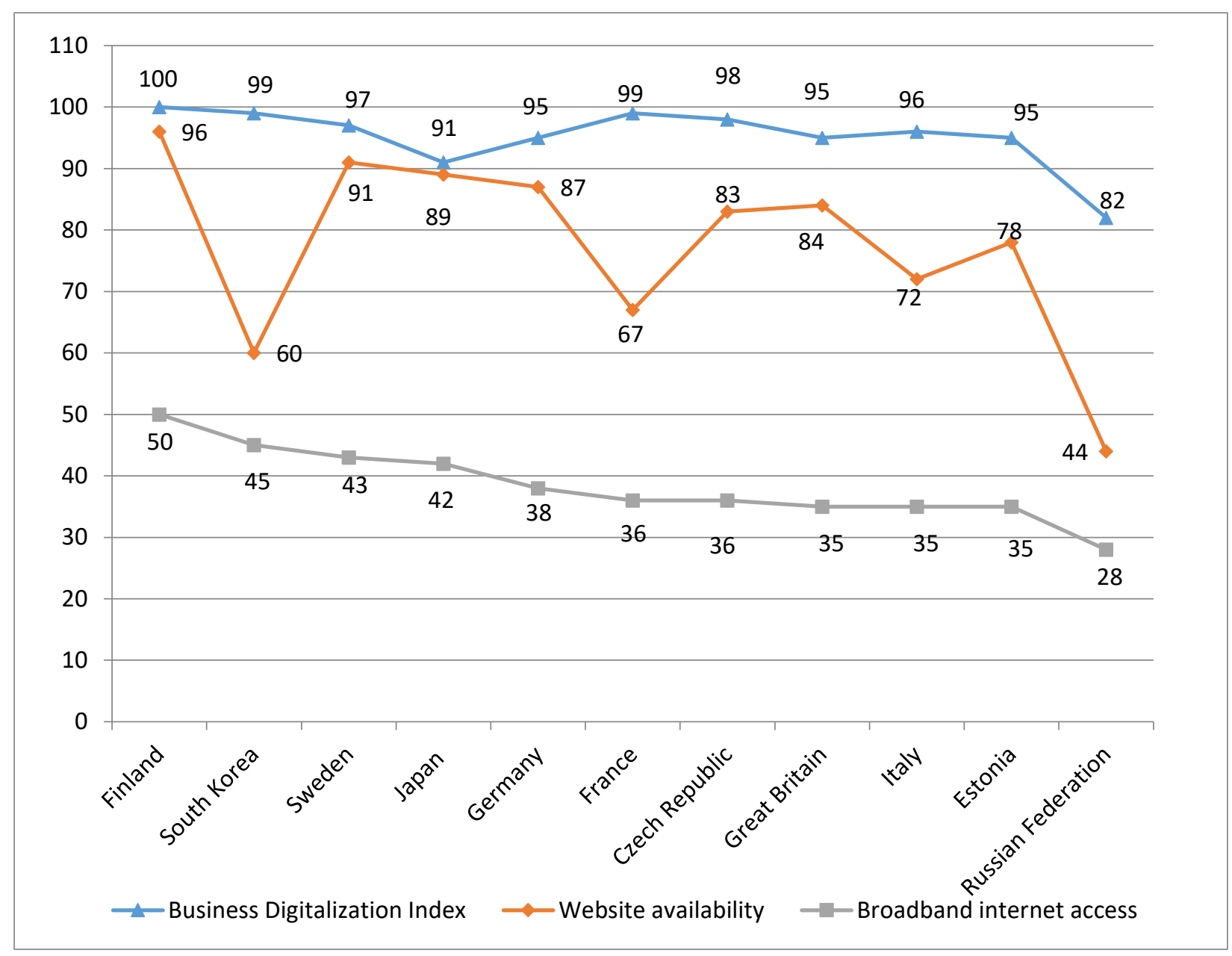

Fig. 3. Digitalization indicators in the business sector

Source: Own results based on Abdrahmanov et al. (2019)

The above data shows that in Finland, the digitalization index of business is one of the highest and is 50, followed by South Korea - 45, Sweden - 43, Japan - 42, Germany - 38. In Russia, the digitalization index of business is one of the lowest, in comparison with other countries, and amounts to only 28 . Furthermore, in Finland, $96 \%$ of the companies have websites, in Sweden - 91\%, in Japan - 89\%, in Germany - 87, in the UK - 84\%. In Russia, only $44 \%$ of companies in the business sector have websites, which is much lower than the Czech Republic - $67 \%$ and Estonia - 78\%. Thus, the entrepreneurial sector in Russia does not take full advantage of the use of digital technologies and prevents the creation of "digital companies", including in the sector of state enterprises and corporations (see Askerov et al. 2018).

Digital economy is Russia is still one the rise, but it is starting to play an increasing role. For example, education is becoming one of the spheres where it is starting to be important. Today, digital educational systems allow for blended learning and the use of artificial intelligence, with which adaptive and individualized learning can be implemented, but, "artificial intelligence cannot completely replace living intelligence because of its lack of the ability to form ideas" (Korogodin 2019). Also, the national project "Healthcare" provides for digital optimization of the work of medical institutions, the maximum accessibility of citizens to quality medical services, reducing the number of medical errors, increasing the effectiveness of managerial decisions in this area.

Today, in the public sector of the Russian economy there is an increase in the potential of information technologies, and the associated increase in the expectations of society (Arkhipova 2016). However, in Russia there are problems associated with a rather low level of computer literacy and Internet activity of citizens. For example, that Internet access in households and the level of Internet use of the total population of most economically developed countries are quite high, while in Russia, similar household indicators are $76 \%$ and $73 \%$ (Abdrakhmanov et al. 2019), respectively. Also, we believe that in our country indicators of Internet use by the population are rather unsatisfactory. According to the Higher School of Economics, in Russia only 4\% of the country's population use the Internet for distance learning, only $4 \%$ of the country's population, for job search $10 \%$, for ordering goods and services $-29 \%$, in the process of financial transactions - $31 \%$ (Abdrakhmanov et al. 2019), which is far below the level of economically developed countries. Thus, the problem of mass use of the 
Internet in households has not yet been resolved in our country, which is an obstacle to the digitalization of the public sector of the economy, as well as the quality and quantity of public services provided to it by the population. Moreover, in Russia, the rate of online interaction of the population with government bodies is also at a rather low level compared to the same indicator of states that are clear favourites in this matter. In particular, scientists at the Higher School of Economics provide the following data characterizing the level of online interaction of the population of the leading countries with the authorities: Sweden - 84\%, Finland - 83\%, Estonia - 78\%, France $68 \%$ and Germany - 53\%. While in Russia, the similar indicator is only 33\% (Abdrakhmanov et al. 2019).

However, despite the problems associated with the process of digital transformation of the public sector of the national economy, the number of users of electronic public services is increasing annually in Russia. Every year in the country there is an increase in the number of people receiving public services in electronic form. In particular, in $2017,42.3 \%$ of the total population used such services in Russia, while in 2014 , only $10.6 \%$ of the population used public services (Abdrakhmanov et al. 2019). Also, annually calculating the online interaction of the state and business sectors of the national economy, the number of companies receiving public services in electronic form is increasing. In $2017,66.6 \%$ of companies in the business sector already received such services, including 39.7\% fully electronic government services (Abdrakhmanov et al. 2019). The data presented indicate positive changes in the processes of digitalization of Russian society. At the same time, the government sector plays an important role in solving the identified problems of the national economy system.

\section{Conclusions}

This paper established quite a number of negative factors that impede the process of digital transformation in the socio-economic system of the national economy in Russia, and above all, the insufficient level of use of digital technologies in the business sector and the low Internet activity of the population.

However, despite the many negative factors that impede the process of digitalization of the public sector of the economy, the practice of introducing electronic public services looks convincing in Russia. Digitalization processes also contribute not only to reducing management costs and improving the quality of public services, but also to increasing labour productivity (Korogodin 2019).

At the same time, we can note a positive trend in the spread of user experience. Today's Russia achieved some minor success in the development of digital technologies. There is an increase in the number of electronic services and an increase in the number of registered users of the all-Russian Unified Portal of Public Services. However, there are some important issues and drawbacks that still need to be improved and that include, for example, the following ones:

- there was no transition of a large number of citizens and organizations to digital channels due to the insufficient attractiveness of systems;

- a convenient, intuitive interface for accessing electronic services has not been created;

- business processes of departments are not transformed with the goal of a complete transition to a digital concept;

- the problem of significant inequality in access to electronic services has not been resolved, i.e. more dependent on public services citizens have significantly less access to them;

- the issues related to the low level of digital literacy of the population are relevant (see Arkhipova 2016).

Thus, the solution of existing problems in the processes of digital transformation of Russian society is possible only with the direct participation of the public sector. We believe that solving the main problems of digital transformation of the national economy, the state should make information available to the public and businesses throughout Russia and at any time convenient for them, and the digital economy system itself must support a multiplicity of electronic sources of information. In the context of digitalization, the created information becomes the public domain, and full partners in the process of electronic interaction are all sectors of the national economy - the public sector, the business sector and households. Therefore, we believe that the priority of digitalization in Russia and the main mission of state economic policy should be the creation of an open information space system that will both ensure the unity and integrity of the national economy system and maintain the status of one of the leading world powers.

\section{References}

Abdrakhmanov GI, Vishnevsky KO, Gohberg LM, Digital economy. Pocket data book, $1^{\text {st }}$ edn. (HSE: Moscow, 2019), 96 p. 
Afonasova MA, Panfilova EE, Galichkina MA, Ślusarczyk B (2019) Digitalization in economy and innovation: the effect on social and economic processes. Polish Journal of Management Studies 19(2):22-32. doi: 10.17512/pjms.2019.19.2.02

Arkhipova ZV (2016) Transformaciya "elektronnogo pravitelstva" v "cifrovoye pravitelstvo". Izvestiya Baikalskogo gosudarstvennogo universiteta 26(5):818-824. doi:org/10.17150/2500-2759.2016.26(5).818-824

Askerov PF, Medvedeva AM, Rabadanov AR, Bogdanova IM, Zvezdichev GJ (2018) Digital Economy as a priority direction for the development of modern innovative entrepreneurship in Russia. Espacios 39(41):30-39

Bolumole YA, Closs DJ, Rodammer FA (2015) The economic development role of regional logistics hubs: a cross-country study of interorganizational governance models. Journal of Business Logistics 36(2):182-198. doi: $10.1111 / \mathrm{jbl} .12088$

Digital Economy of the Russian Federation (2017) The programme of the digital economy. http://static.government.ru/media/files/9gFM4FHj4PsB79I5v7yLVuPgu4bvR7M0.pdf. Accessed 10 November 2019

Korogodin IT (2019) Izmeneniya trudovykh otnosheniy pri perekhode k cifrovoy tekhnologii. Ekonomika truda $1(6): 77-88$

Kotov AV (2018) The Polar Ruhr: Structural Policy in the Monocities of the Russian Arctic. Problems of Economic Transition 60(10-11):828-846. doi: 10.1080/10611991.2018.1628602

Omonov ZK, Veretennikova AY (2016) Quantitative Scaling of Social Innovations. Montenegrin Journal of Economics 12(4):77-86. doi: 10.14254/1800-5845/2016.12-4.7

Roshchanka V, Evans M (2016) Scaling up the energy service company business: market status and company feedback in the Russian Federation. Journal of Cleaner Production 112:3905-3914. doi: 10.1016/j.jclepro.2015.05.078

Veselovsky MY, Izmailova MA, Yunusov LA, Yunusov IA (2019) Quality of Digital Transformation Management on the Way of Formation of Innovative Economy of Russia. Quality-Access to Success 20(169):66-71

Zemskova IA (2018) Transformaciya kachestva gosudarsvennykh uslug pod vliyaniyem cifrovizacii gosudarstvennykh organov. Vestnik Saratovskogo gosudarstvennogo socialno-ekonomicheskogo universiteta 3(72):23-28. 